\title{
Intraoperative ultrasonography in nine dogs with intra-abdominal neoplasm suspect
}

\author{
Daniella Matos da Silva ${ }^{1 *}$ Marco Antonio Ferreira da Silva ${ }^{1}$ Giovana Paladino Vieira ${ }^{1}$ \\ Aline Iara Franciosi ${ }^{1}$ Paula Cristina de Freitas Pezzini ${ }^{1}$ Simone Domit Guérios ${ }^{1}$ Tilde Rodrigues Froes ${ }^{1}$
}

${ }^{1}$ Setor de Ciências Agrárias, Departamento de Medicina Veterinária, Universidade Federal do Paraná (UFPR), 80035-050, Curitiba, PR, Brasil. E-mail: danimsca@hotmail.com. "Corresponding author.

\begin{abstract}
Intraoperative ultrasonography (IOUS) is used in medicine for diagnosis and guidance during oncologic surgery. The aims of this study were to assess the performance, feasibility, advantages and difficulties of the IOUS technique in dogs with suspected intra-abdominal tumors. The study included nine client-owed dogs that had suspected intra-abdominal tumors (spleen, liver or bowel) based on transabdominal ultrasound examination and that were subsequently referred for exploratory laparotomy surgery. During surgery, IOUS was performed; results of preoperative transabdominal ultrasonography, inspection by the surgeon and IOUS were compared on a case-by-case basis. IOUS was helpful in determining lesion resection in all cases. Lesions detected solely by the use of IOUS were observed in seven out of nine cases. Analysis of these cases demonstrated that IOUS can be a tool to assist during oncology surgery on the liver, spleen or bowel. Dogs with hepatic tumors can have small non-palpable intraparenchymal nodules, which may be visible by IOUS. Key words: biopsy, bowel; hemangiosarcoma, liver; spleen.
\end{abstract}

Ultrassonografia intraoperatória em nove cães com suspeita de neoplasia intra-abdominal

RESUMO: A ultrassonografia intraoperatória (USIO) é usada na medicina como método de diagnóstico e orientação para procedimentos em cirurgia oncológica. Os objetivos desse estudo foram avaliar a performance, viabilidade, vantagens e dificuldades da técnica de USIO em cães com suspeita de neoplasia intra-abdominal. $O$ estudo incluiu nove cães com suspeita de neoplasia intra-abdominal (baço, figado ou intestino) baseada em exame ultrassonográfico transabdominal e que foram subsequentemente encaminhados para laparotomia exploratória. Durante o procedimento cirúrgico, a USIO foi realizada e os resultados da ultrassonografia transabdominal pré-operatória, inspeção e palpação realizada pelo cirurgião e USIO foram comparados com base em uma avaliação caso-a-caso. A USIO contribuiu para determinar a área de ressecção das lesões em todos os casos. Lesões detectadas somente pela USIO foram observadas em sete dos nove casos. A análise dos casos demostrou que a USIO pode auxiliar durante a cirurgia oncológica do figado, baço e intestino. Cães com neoplasia hepática podem ter lesões pequenas intraparenquimatosas e não palpáveis pelo cirurgião, mas que podem ser verificadas pela USIO.

Palavras-chave: baço, biopsia, figado, hemangiossarcoma, intestino.

\section{INTRODUCTION}

Intraoperative ultrasonography (IOUS) has been used in medicine since the1960s, first for the evaluation of brain tumors and renal and biliary calculi (KANE, 2004). Currently, IOUS is used in medicine for diagnosis and guidance during surgical exploration in a variety of organs, especially in neurosurgery, pancreatic, renal and hepatobiliary surgery (KANE, 2004; MARCAL et al., 2013).

Despite advancements in preoperative imaging with computed tomography and magnetic resonance imaging, IOUS provides diagnostic information during surgery that is capable of changing the surgical plan. Benefits of using this technique are intraoperative guidance and correct localization of lesions, assistance in determining lesion resection and surgical planning, metastatic assessment and local staging. These advantages make IOUS a helpful tool, mainly during oncologic surgery (HATA et al., 2011; MARCAL et al., 2013). In medicine, during oncological liver surgery, small non-palpable intraparenchymal tumors can only be detected by the use of IOUS (CERWENKA et al., 2004; HATA et al., 2011).

There are few studies investigating the use of IOUS in veterinary medicine. Most published studies are restricted to neurosurgery on the spinal cord (TANAKA et al., 2006; NANAI et al., 2007; BONELLI et al., 2015). Only two papers have described the use of IOUS to evaluate intra- 
abdominal organs in dogs. JIMÉNEZ et al. (2011) evaluated the contrast-enhanced ultrasonography of normal canine jejunum using an intraoperative approach and SPINELLA et al. (2006) assessed the laparoscopic ultrasonography in six dogs with spontaneous abdominal disease.

To the authors' knowledge, the use of IOUS in conventional abdominal surgery in dogs with suspected intra-abdominal neoplasms has not previously been described. The goals of this study were to present the performance, feasibility, advantages and difficulties of intra-abdominal IOUS technique in dogs with suspected abdominal tumors.

\section{MATERIALS AND METHODS}

A prospective cross-sectional and descriptive study was conducted over a period of 8 months at our Veterinary Teaching Hospital. Dogs referred to the ultrasonography service were considered for the study. Inclusion criteria were dogs of any age, gender or breed that had intra-abdominal organ neoplasm suspected based on preoperative transabdominal ultrasound examination. All patients included were referred for exploratory laparotomy surgery. Preoperative transabdominal ultrasonography exams were performed using a high-resolution ultrasound machine $\left(\mathrm{MyLab}^{\mathrm{TM}} 30\right.$ Vet Gold, Esaote, Italy). Transducers with convex (CA123, Esaote, Italy) and linear (LA523, Esaote, Italy) arrays, ranging from 5.0 to $12 \mathrm{MHz}$, according to the size of the animal and the organ to be evaluated, were used. A systematic evaluation of all organs of the abdomen was performed, regardless of clinical suspicion. Radiology residents working under experienced radiologists' supervision performed the examinations.

The surgeon responsible for the case was informed of the preoperative transabdominal ultrasonography findings and these results were correlated with other clinical aspects in order to determine the surgical planning. The surgical procedure was performed within 48 hours of the ultrasound examination.

The abdomen was surgically accessed by ventral midline incision and the surgeon performed an initial evaluation of the neoplasm-suspected organ (inspection and palpation of organs where primary or metastatic lesions were suspected). After this evaluation, IOUS was performed using the same machine that was used preoperatively for transabdominal ultrasonography (MyLab ${ }^{\mathrm{TM}} 30$ Vet Gold, Esaote, Italy); however, only the linear transducer (LA523, Esaote, Italy) was used (6.6 to $12.0 \mathrm{MHz})$. Scanning of the organ(s) of interest was performed, considering the clinical status of the patient; if unstable hemodynamic status was observed, the IOUS was interrupted in order to ensure that surgical time was not increased. The time required for IOUS was not recorded. The transducer, with a small amount of ultrasound gel, and its cable were covered with a sterile disposable cover for intraoperative equipment (MPaniagua, Brazil). The transducer was placed directly on the surface of the organs. Whenever possible, evaluated organ was partially or completely externalized from abdominal cavity to facilitate contact with the transducer. All IOUS examinations were undertaken by the surgeon; however, the radiologist who performed the preoperative transabdominal ultrasound was also present in the surgical room, assisting in the process for recording images.

The preoperative transabdominal and IOUS images were recorded and compared. New lesions were identified and the contribution and limitations of the IOUS were evaluated on a caseby-case basis. The main suspected neoplasm lesion was resected for histopathological confirmation of neoplasia. Additional lesions identified by IOUS were resected or biopsied, whenever possible, and sent for histopathological diagnosis.

\section{RESULTS}

Nine dogs with liver, spleen or bowel tumors were included in this study. Clinical characteristics, preoperative transabdominal ultrasound findings, surgeon findings and new lesions detected solely by IOUS are summarized in table 1 . The preoperative transabdominal ultrasonography diagnosis suspected of neoplasm in the spleen ( 3 dogs), liver (2 dogs), both liver and spleen ( 2 dogs) and intestine (1 dog). Presence of intra-abdominal free fluid was observed in four dogs (two with strictly splenic tumors and two with both hepatic and splenic tumors). Abdominocentesis was performed and analysis of the fluid was consistent with hemoperitoneum in these dogs.

During surgery, neoplasm-suspected organs were inspected, and lesions were palpated in eight out of nine cases. In one dog (number 5), the spleen nodules were neither visible nor palpable by the surgeon.

Hepatic IOUS was performed in eight dogs (3 for metastatic research due to suspected splenic tumor, 2 with suspected primary or metastatic hepatic tumor and 3 with suspected of both splenic and hepatic tumors). Intestinal IOUS was performed in one dog (number 4), as was splenic IOUS (number 5). The hepatic IOUS was performed in all dogs with 
Table 1 - Clinical characteristics, preoperative transabdominal ultrasound findings, surgeon findings and new lesions detected solely by IOUS in nine dogs evaluated by intra-abdominal IOUS.

\begin{tabular}{|c|c|c|c|c|}
\hline Dog & $\begin{array}{l}\text { Age, Sex, } \\
\text { Breed }\end{array}$ & $\begin{array}{c}\text { Number, size, and probable location } \\
\text { of lesions (transabdominal } \\
\text { ultrasound) }\end{array}$ & $\begin{array}{l}\text { Surgical findings (inspection and } \\
\text { palpation of the surgeon) }\end{array}$ & $\begin{array}{l}\text { New lesions detected } \\
\text { solely by IOUS }\end{array}$ \\
\hline 1 & $\begin{array}{c}\text { 9y, } \mathrm{F}^{\mathrm{a}} \\
\text { Rottweiler }\end{array}$ & $\begin{array}{c}2 \text { masses, } 8 \times 6 \mathrm{~cm} \text { and } 6 \times 6 \mathrm{~cm} \text {, in left } \\
\text { hepatic lobes }\end{array}$ & $\begin{array}{l}\text { Liver: } 2 \text { masses in left lobes, firm } \\
\text { consistency in papillary process of } \\
\text { caudate lobe }\end{array}$ & $\begin{array}{l}\text { Liver: small nodule in } \\
\text { right medial lobe }\end{array}$ \\
\hline 2 & $\begin{array}{l}12 \mathrm{y}, \mathrm{M}^{\mathrm{b}} \\
\text { Labrador } \\
\text { retriever }\end{array}$ & 1 mass, $6 \times 5 \mathrm{~cm}$, in tail of spleen ${ }^{1}$ & $\begin{array}{l}\text { Spleen: ruptured mass, active bleeding } \\
\text { Liver: small nodules distributed } \\
\text { throughout the surface of organ }\end{array}$ & $\begin{array}{l}\text { Liver: countless } \\
\text { intraparenchymal nodules }\end{array}$ \\
\hline 3 & $\begin{array}{l}9 \mathrm{y}, \mathrm{F}^{\mathrm{a}} \\
\text { Labrador } \\
\text { retriever }\end{array}$ & $\begin{array}{c}1 \text { mass, } 6 \times 5 \mathrm{~cm} \text {, heterogeneous in left } \\
\text { hepatic lobes }\end{array}$ & Liver: 1 mass in left medial lobe & $\begin{array}{l}\text { Liver: } 2 \text { small nodules in } \\
\text { left medial lobe and in left } \\
\text { lateral lobe }\end{array}$ \\
\hline 4 & $\begin{array}{l}\text { 9y, } \mathrm{M}^{\mathrm{b}} \\
\text { Standard } \\
\text { Poodle }\end{array}$ & $\begin{array}{c}1 \mathrm{mass}, 3 \mathrm{~cm} \text { of extension, in the small } \\
\text { intestine }\end{array}$ & Small intestine: 1 well delimited mass & None \\
\hline 5 & $\begin{array}{l}11 \mathrm{y}, \mathrm{F}^{\mathrm{a}} \\
\text { Schnauzer }\end{array}$ & $\begin{array}{l}\text { Multiple nodules up to } 1.5 \mathrm{~cm} \\
\text { (diameter) in the spleen; nodules } \\
\text { interspersed in a heterogeneous and } \\
\text { hyperechoic liver }\end{array}$ & $\begin{array}{l}\text { Liver: hepatomegaly, uneven surface } \\
\text { with multiple small nodules }\end{array}$ & None $^{3}$ \\
\hline 6 & $\begin{array}{l}10 \mathrm{y}, \mathrm{M}^{\mathrm{b}} \\
\text { Labrador } \\
\text { retriever }\end{array}$ & $\begin{array}{c}1 \text { mass, } 6 \times 5 \mathrm{~cm} \text {, in tail of spleen; } \\
\text { multiple nodules up to } 3 \mathrm{~cm} \text { (diameter) } \\
\text { distributed throughout the liver } \\
\text { parenchyma }^{1}\end{array}$ & $\begin{array}{l}\text { Spleen: ruptured mass, active bleeding } \\
\text { Liver: small nodules distributed } \\
\text { throughout the surface of organ, with } \\
\text { active bleeding }\end{array}$ & $\begin{array}{l}\text { Liver: countless } \\
\text { intraparenchymal nodules }\end{array}$ \\
\hline 7 & $\begin{array}{l}10 y, F^{a} \\
\text { German } \\
\text { Shepherd } \\
\quad \text { dog }\end{array}$ & $\begin{array}{l}1 \text { mass, } 8 \times 8 \mathrm{~cm} \text {, in left hepatic lobes; } \\
\text { multiple nodules up to } 1.5 \mathrm{~cm} \\
\text { (diameter) distributed throughout the } \\
\text { liver parenchyma; multiple nodules } \\
\text { up to } 2 \mathrm{~cm} \text { (diameter) in the spleen }{ }^{1}\end{array}$ & $\begin{array}{l}\text { Liver: ruptured mass in left lateral lobe } \\
\text { with active bleeding, multiple small } \\
\text { nodules throughout the surface of organ } \\
\text { Spleen: nodules with active bleeding }\end{array}$ & $\begin{array}{l}\text { Liver: countless } \\
\text { intraparenchymal nodules }\end{array}$ \\
\hline 8 & $\begin{array}{l}12 \mathrm{y}, \mathrm{M}^{\mathrm{b}} \\
\text { American } \\
\text { Pit Bull } \\
\text { Terrier }\end{array}$ & 1 mass, $7 \times 6 \mathrm{~cm}$, adjacent to the spleen & Spleen: 1 mass & $\begin{array}{l}\text { Liver: small nodule in } \\
\text { right lateral lobe }\end{array}$ \\
\hline 9 & $\begin{array}{l}\text { 9y, } \mathrm{F}^{\mathrm{a}} \\
\text { German } \\
\text { Shepherd } \\
\text { dog }\end{array}$ & 1 mass, $5 \times 4 \mathrm{~cm}$, in the spleen ${ }^{1}$ & $\begin{array}{c}\text { Spleen: ruptured mass Liver: } 2 \text { small } \\
\text { nodules in left lateral lobe and } 1 \text { in } \\
\text { square lobe }\end{array}$ & $\begin{array}{l}\text { Liver: countless } \\
\text { intraparenchymal nodules }\end{array}$ \\
\hline
\end{tabular}

${ }^{a}$ Female, ${ }^{b}$ Male, ${ }^{1}$ Presence of free abdominal fluid, ${ }^{2}$ Euthanasia during the surgery (inoperable lesions), ${ }^{3}$ Lesion previously detected by preoperative transabdominal ultrasound.

liver or spleen tumors; splenic IOUS was performed in dog number 5 due to lesions were not identified by the surgeon despite visible by preoperative transabdominal ultrasonography; and intestinal IOUS was performed in dog number 4 to help define margins for enterectomy.

IOUS identified additional lesions that were undetected by the surgeon in eight out of nine cases (all cases except the intestinal tumor). Comparing IOUS with preoperative transabdominal ultrasound, IOUS were able to identify more lesions that were previously undetected in seven out of the nine dogs. figure 1 shows examples of lesions detected by IOUS.
Information provided by IOUS directly influenced the surgical protocol or contributed to the surgical decision in all cases. Notably, limitations to the full use of IOUS were documented in six cases. The contributions and limitations of IOUS are shown in table 2.

Histopathology of the resected main lesions confirmed the neoplasm suspected in seven out of the nine dogs. Non-neoplasic lesions (including non-palpable lesions biopsied by IOUS guidance) were verified in dogs numbers 3 and 5. All dogs with splenic masses, except number 5 , had splenic hemangiosarcoma (histopathologically confirmed). Hepatic tissue biopsied by IOUS guidance of these 


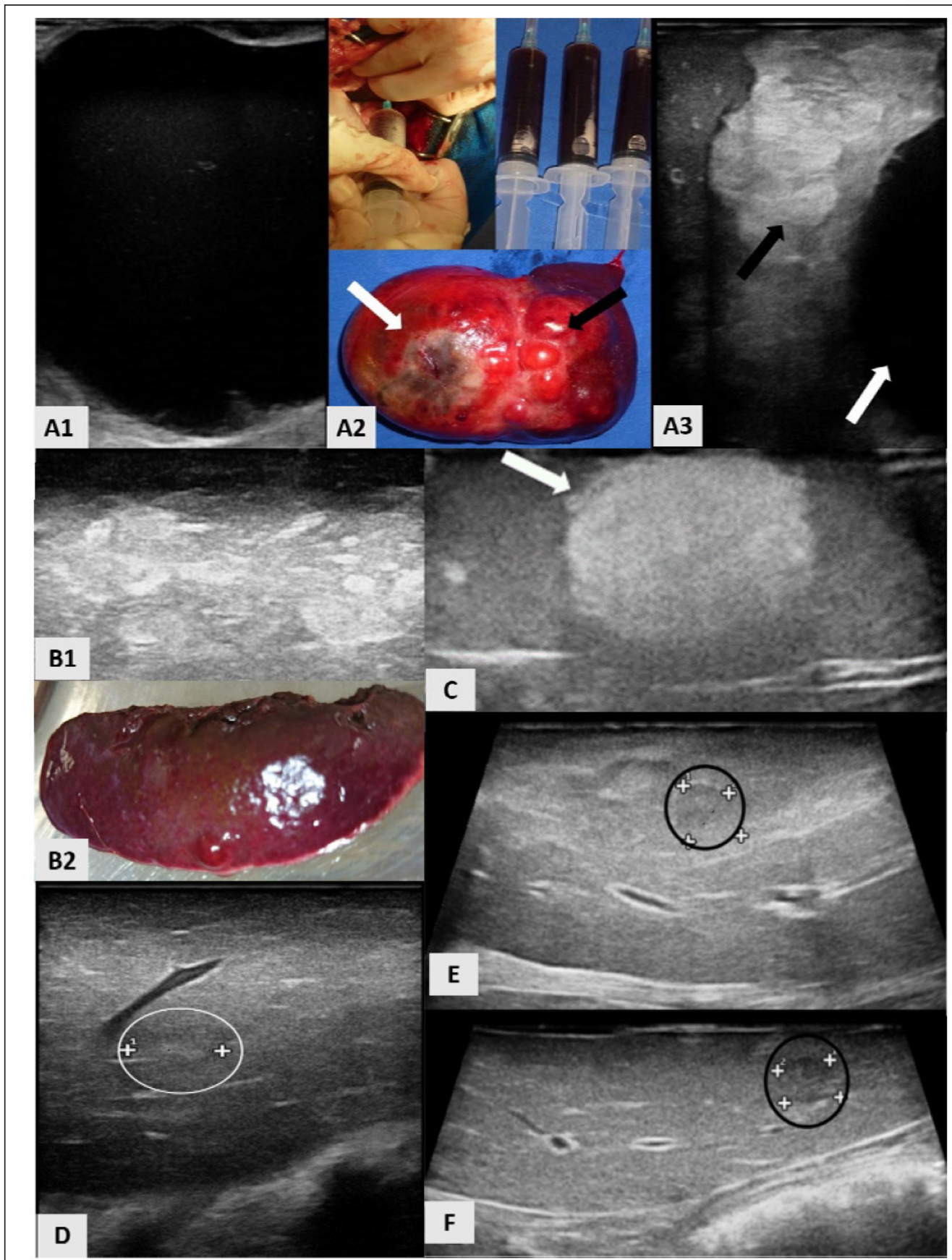

Figure 1 - IOUS in dogs with intra-abdominal tumors. A1) IOUS liver image in a dog with cholangiocarcinoma (dog number 1). Presence of anechoic non-vascular mass in left medial hepatic lobe. A2) Image-guided drainage of mass content, syringes with content drained and mass appearance after left lobectomy. A2 and A3) Heterogeneous mass in left lateral hepatic lobe (black arrow) and anechoic mass in left medial hepatic lobe (white arrow). B1) Liver IOUS image in dog with hepatic hemangiosarcoma (dog number 2 ) showing countless intraparenchymal hyperechoic nodules and (B2) liver fragment of the same region. C) Splenic IOUS image (dog number 5) showing non-palpable hyperechoic nodule (arrow). D) Non-palpable isoechogenic intraparenchymal nodule (white circle) in right medial hepatic lobe, visible solely by IOUS. Dog with cholangiocarcinoma in the left hepatic lobes (same case showed in A). E and F) Liver IOUS image showing two intraparenchymal non-palpable hypoechoic nodules (black circles), measuring 0.9 $\mathrm{cm}$ in left medial lobe and $0.6 \mathrm{~cm}$ in left lateral lobe (dog number 3 ). 
Table 2 - Contribution and limitations of IOUS during surgery for the nine dogs presented in table 1.

\begin{tabular}{|c|c|c|}
\hline Dog & Contribution of IOUS & Limitations of IOUS \\
\hline 1 & $\begin{array}{l}\text { Drainage of mass content (anechoic non-vascular) in medial left hepatic lobe, } \\
\text { facilitating hepatic lobectomy (Figure 1A). Resection of hepatic papillary } \\
\text { process of caudate lobe. Detection of new lesion in hepatic right medial lobe }\end{array}$ & $\begin{array}{l}\text { Difficult access to right hepatic lobes, } \\
\text { impossible image-guided biopsy of non- } \\
\text { palpable nodule* }\end{array}$ \\
\hline 2 & $\begin{array}{l}\text { Detection of countless nodules in the liver (liver intraoperative staging). } \\
\text { Decision of hepatic biopsy in right medial lobe that presented } 3 \text { palpable } \\
\text { nodules and countless identified solely by IOUS (Figure 1B) }\end{array}$ & None \\
\hline 3 & $\begin{array}{l}\text { Detection of new lesions in hepatic left lobes and image-guided biopsy of } \\
\text { them (Figure } 1 \mathrm{E} \text { and } \mathrm{F} \text { ) }\end{array}$ & $\begin{array}{c}\text { Difficult access to right and caudate hepatic } \\
\text { lobes }\end{array}$ \\
\hline 4 & $\begin{array}{c}\text { Evaluation of transitional zone between loss of mural detail and normal } \\
\text { bowel. Definition of margins for resection point }\end{array}$ & None \\
\hline 5 & $\begin{array}{l}\text { Detection of non-palpable nodule in spleen and its image-guided biopsy } \\
\text { (Figure 1C) }\end{array}$ & $\begin{array}{c}\text { Difficult access to right and quadrate hepatic } \\
\text { lobes }\end{array}$ \\
\hline 6 & $\begin{array}{l}\text { Detection of countless nodules in the liver (liver intraoperative staging). } \\
\text { Support to decision of euthanasia because of number of intraparenchymal } \\
\text { liver nodules and active bleeding }\end{array}$ & None \\
\hline 7 & $\begin{array}{c}\text { Detection of countless intraparenchymal nodules (liver). Support to decision } \\
\text { of hepatic lobectomy only in lobe with active bleeding }\end{array}$ & $\begin{array}{l}\text { Difficult access to hepatic lobes. } \\
\text { Hemodynamically unstable patient during } \\
\text { surgery limiting careful IOUS }\end{array}$ \\
\hline 8 & $\begin{array}{c}\text { Detection of new lesion in right lateral lobe (liver). Liver intraoperative } \\
\text { staging (dog with malignant spleen tumor) }\end{array}$ & $\begin{array}{l}\text { Difficult of access to right hepatic lobes, } \\
\text { impossible image-guided biopsy of non- } \\
\text { palpable nodule }\end{array}$ \\
\hline 9 & $\begin{array}{l}\text { Detection of new lesions in all liver. Liver intraoperative staging (dog with } \\
\text { malignant spleen tumor). Decision of just incisional liver biopsy, due large } \\
\text { number of nodules visible by IOUS }\end{array}$ & $\begin{array}{l}\text { Difficult access to hepatic lobes. } \\
\text { Hemodynamically unstable patient during } \\
\text { surgery limiting careful IOUS }\end{array}$ \\
\hline
\end{tabular}

*incomplete contact of the probe with the liver surface.

dogs confirmed metastatic hemangiosarcoma in four animals (numbers 2, 6, 7 and 9). Hepatic tissue biopsied from the left medial lobe of the dog number 8 (with splenic hemangiosarcoma) was compatible with fibrinous peritonitis. Dog number 1 had cholangiocarcinoma in the left lobe of the liver and portal fibrosis in the hepatic pappilary process of the caudate lobe. The histopathology of the dog with an intestinal mass (number 4) was compatible with a poorly differentiated sarcoma.

\section{DISCUSSION}

This study of cases showed the applicability of the IOUS technique in dogs during exploratory laparotomy for tumor investigation in the spleen, liver and bowel. The IOUS contributed to resection assistance and the decision regarding surgical protocol in all cases. Furthermore, the technique revealed new lesions that were neither visible nor palpable by the surgeon and/or that could not be observed via preoperative transabdominal ultrasound.

In all of the dogs in which IOUS was used in this study to evaluate the liver, it was possible to detect new non-palpable intraparenchymal lesions. The use of IOUS during oncological surgery played an important role in identifying new lesions, which generally led to changes in surgical management, in accordance with the present study (CERWENKA et al., 2004; HATA et al., 2011). In medicine, IOUS in liver surgery, associated with bimanual palpation and visual inspection, changed preoperative scheduled hepatectomy in $8 \%$ to $72 \%$ of the patients (HATA et al., 2011; HOCH et al., 2015). The value of IOUS is greater in detecting non-palpable small lesions $(<1 \mathrm{~cm})$ located deep below the liver surface (HATA et al., 2011).

Based on IOUS findings, biopsy diagnosis of the new lesions was attempted. The ability of IOUS to provide real-time imaging of the organs of interest, with accurate small lesion detection and characterization, establishes the important role of IOUS in intraoperative guidance for either biopsy or resection (MARCAL et al., 2013). However, differentiation between malignant and benign lesions is not possible with only IOUS evaluation. It is interesting to note that definitive histopathological diagnoses excluded the possibility of a neoplasm in some cases in the present study, including a number 
of lesions identified only by IOUS. These results reinforce the need for histopathological evaluation of all suspected lesions, identified by preoperative transabdominal ultrasound or IOUS (GASCHEN, 2009; MARCAL et al., 2013).

The use of IOUS during abdominal surgery allows for the direct application of a highfrequency transducer on the surface of the organ(s) of interest, with no obstacle in the abdominal wall to the penetration of sound waves. Moreover, it is possible to avoid other abdominal structures such as the bowel, when a parenchymatous organ is evaluated (LUCK \& MADDERN, 1999). We were able to obtain highquality IOUS images in almost all cases using a linear high-frequency transducer. Exceptions included evaluation of the right and caudate hepatic lobes due to incomplete contact of the probe with the liver surface. The complete and careful IOUS scanning of all lobes of the liver was a limitation of our study. Because access was difficult, some lesions identified solely by IOUS could not be biopsied. However, resection of large hepatic masses (dogs number 1 and 3 ) prior to IOUS examination of the remaining lobes decreased the physical limitation of transducer access to the organ.

Small and specific intraoperative probes could have decreased the difficulty of access to the liver during IOUS in dogs, improving the quality of the assessment. Although, a standard transabdominal transducer can be used for intra-abdominal IOUS, a limitation is the bulkiness of the probe (KANE, 2004; PATEL \& ROH, 2004).

Hepatic IOUS has not been described in dogs. Thus, there is no standardization for the use of this technique in this species. In human beings, IOUS of the liver is a methodical and systematic approach. The organ is mobilized by division of the round, falciform and triangular ligaments. Sonographically, the hepatic veins are followed from the vena cava to the periphery; all segment branches of the portal vein are identified starting from the hilus and the parenchyma is carefully examined for lesions. Size, number, location, hepatic segments involved and the relationship of the lesions to vascular and biliary structures are noted (CERWENKA et al., 2004; PATEL \& ROH, 2004).

In the present study, hepatic IOUS was performed using lobar division aiming To evaluate all liver parenchyma. However, due to the difficulties reported, not all liver lobes were accessed properly. The access of the probe to all liver parenchyma was also influenced by the dogs size. The difficulty in access was greater in large, deep-chested dogs. Additionally, some patients were hemodynamically unstable during surgery and careful IOUS exam was not possible in those dogs. IOUS of the liver in people requires an additional 10-15 minutes of operating time (RIFKIN et al., 1987). IOUS-guided-biopsy of all new lesions also increases the surgical time, making it difficult in unstable patients who require a faster procedure. This limitation could be decreased with an experienced intraoperative sonographer (RIFKIN et al., 1987).

Role of IOUS in the real-time characterization of tumors and precise definition of their margins (MARCAL et al., 2013) was accomplished in our study, especially during the intraoperative examination of the dog with intestinal sarcoma (dog number 4). Lesion and its precise transition zone between the loss of mural detail and normal bowel were identified using IOUS. This information contributed to definition of the resection point, ensuring negative margins.

In comparison with preoperative transabdominal ultrasound examination, IOUS identified more lesions in dogs with splenic tumors (number 2, 6, 7 and 9) and free peritoneal fluid. The presence of free peritoneal fluid can increase the difficulty of the transabdominal ultrasonography (GASCHEN, 2009). Two dogs with free peritoneal fluid had only splenic tumors that were visible by preoperative transabdominal ultrasound. In addition, the same dogs had liver lesions identified upon inspection by the surgeon and additional countless intraparenchymal lesions visible solely by IOUS. These lesions were confirmed by histopathology as hepatic hemangiosarcoma.

A recent study evaluated the presence or absence of macroscopic liver lesions in 79 dogs with confirmed splenic hemangiosarcoma. Only $50 \%$ of dogs with grossly abnormal livers had hemangiosarcoma metastasis, and no dog with a grossly normal liver had metastasis that was detected by liver histopathology (CLENDANIEL et al., 2014). In accordance with our study, the use of liver IOUS might improve metastatic assessment and local staging in dogs with splenic hemangiosarcoma. A grossly normal liver during inspection by the surgeon can have lesions visible by IOUS, serving to direct the biopsy site.

An important limitation of this study is the small number of dogs included. Future studies should evaluate the value of IOUS during abdominal surgery in larger samples, which would allow for standardization of the technique and comparison of the sensitivity and specificity of IOUS with other imaging methods. Variability of lesions and the 
use of a standard transabdominal transducer during the surgery also limited the study. Unfortunately, there was not possible standardization of methods. However, additional occult lesions could be reported. Complications, such as contamination of the sterile field, did not occur, and the results were similar to those obtained with IOUS in medicine.

\section{CONCLUSION}

The present study demonstrated that IOUS can be a helpful tool during tumor resection surgery in dogs. IOUS may guide intraoperative biopsy and improve surgical staging in dogs with intra-abdominal tumors. It is a safe and non-invasive technique that should be encouraged in veterinary medicine.

\section{BIOETHICS AND BIOSSECURITY COMMITTE APPROVAL}

This study was approved by the Comitê de Ética em Uso Animal do Campus de Ciências Agrícolas of the Universidade Federal do Paraná, Brazil (protocol N. 011/2014).

\section{REFERENCES}

BONELLI, M.A. et al. Intraoperative ultrasonography of the vertebral canal in dogs. Arquivo Brasileiro de Medicina Veterinária e Zootecnia, v. 67, p.655-663, 2015. Available from: <http://www. scielo.br/scielo.php?pid=S0102-09352015000300655\&script $=\mathrm{sci}$ arttext>. Accessed: Nov. 05, 2015. doi: 10.1590/1678-4162-7494.

CERWENKA, H. et al. Intraoperative ultrasonography in liver surgery: a critical evaluation. European Surgery, v.36, p.280-284 2004. Available from: <http://link.springer.com/article/10.1007\% 2Fs10353-004-0092-5>. Accessed: Nov. 05, 2015. doi: 10.1007/ s10353-004-0092-5.

CLENDANIEL, D.C. et al. Association between macroscopic appearance of liver lesions and liver histology in dogs with splenic hemangiosarcoma: 79 cases (2004-2009). Journal of the American Animal Hospital Association, v.50, p.6-10, 2014. Available from: $<$ http://www.ncbi.nlm.nih.gov/pubmed/25001171>. Accessed: Nov. 05, 2015. doi: 10.5326/JAAHA-MS-6059.

GASCHEN, L. Update on hepatobiliary imaging. Veterinary Clinics of North America: Small Animal Practice, v.39, p.439-467, 2009 Available from: <http://www.ncbi.nlm.nih.gov/pubmed/19524788>. Accessed: Nov. 05, 2015. doi: 10.1016/j.cvsm.2009.02.005.

HATA, S. et al. Value of visual inspection, bimanual palpation, and intraoperative ultrasonography during hepatic resection for liver metastases of colorectal carcinoma. World Journal of Surgery, v.35, p.2779-2787, 2011. Available from: <http://link.springer. com/article/10.1007\%2Fs00268-011-1264-7>. Accessed: Nov. 05, 2015. doi: 10.1007/s00268-011-1264-7.

$\mathrm{HOCH}, \mathrm{G}$. et al. Is intraoperative ultrasound still useful for the detection of colorectal cancer liver metastases? HPB (Oxford), v.17, p.514-519, 2015. Available from: <http://www.ncbi.nlm.nih. gov/pubmed/25728974>. Accessed: Nov. 05, 2015. doi: 10.1111/ hpb. 12393

JIMÉNEZ, D.A. et al. Intraoperative contrast-enhanced ultrasonography of normal canine jejunum. Veterinary Radiology \& Ultrasound, v.52, p.196-200, 2011. Available from: <http://onlinelibrary.wiley.com/ doi/10.1111/j.1740-8261.2010.01767.x/abstract>. Accessed: Nov. 05, 2015. doi: 10.1111/j.1740-8261.2010.01767.x.

KANE, R.A. Intraoperative ultrasonography, history, current state of the art, and future directions. Journal of Ultrasound in Medicine, $\mathrm{v}$. 23, p.1407-1420, 2004. Available from: <http://www.jultrasoundmed. org/content/23/11/1407.long >. Accessed: Nov. 05, 2015.

LUCK, A.J.; MADDERN, G.J. Intraoperative abdominal ultrasonography. British Journal of Surgery, v.86 p.5-16, 1999. Available from: $<$ http://www.ncbi.nlm.nih.gov/pubmed/10027353>. Accessed: Nov. 05, 2015. doi: 10.1046/j.1365-2168.1999.00990.x.

MARCAL, L.P. et al. Intraoperative abdominal ultrasound in oncologic imaging. World Journal of Radiology, v.28, p.51-60, 2013. Available from: <http://www.ncbi.nlm.nih.gov/pmc/articles/ PMC3650205>. Accessed: Nov. 05, 2015. doi: 10.4329/wjr.v5.i3.51.

NANAI, B. et al. Use of intraoperative ultrasonography in canine spinal cord lesions. Veterinary Radiology \& Ultrasound, v.48, p.254-261, 2007. Available from: <http://www.ncbi.nlm.nih.gov/ pubmed/17508514>. Accessed: Nov. 05, 2015. doi: 10.1111/j.17408261.2007.00239.x.

PATEL, N.A.; ROH, M.S. Utility of intraoperative liver ultrasound. Surgical Clinics of North America, v.84, p.513-524, 2004. Available from: <http://www.ncbi.nlm.nih.gov/pubmed/15062659>. Accessed: Nov. 05, 2015. doi: 10.1016/j.suc.2003.12.008.

RIFKIN, M.D. et al. Intraoperative ultrasound of the liver. An important adjunctive tool for decision making in the operating room. Annals of Surgery, v.205, p.466-472, 1987. Available from: <http://www.ncbi.nlm.nih.gov/pmc/articles/PMC1493038>. Accessed: Nov. 05, 2015.

SPINELLA, G. et al. Laparoscopic ultrasonography in six dogs. Veterinary Radiology \& Ultrasound, v.47, p.283-286, 2006. Available from: <http:// onlinelibrary.wiley.com/doi/10.1111/j.1740-8261.2006.00141.x/abstract>. Accessed: Nov. 05, 2015. doi: 10.1111/j.1740-8261.2006.00141.x.

TANAKA, H. et al. Intraoperative spinal ultrasonography in two dogs with spinal disease. Veterinary Radiology \& Ultrasound, v.47, p.99-102, 2006. Available from: <http://onlinelibrary.wiley. com/doi/10.1111/j.1740-8261.2005.00114.x/abstract $>$. Accessed: Nov. 05, 2015. doi: 10.1111/j.1740-8261.2005.00114.x. 